\title{
QUEEN'S
UNIVERSITY
BELFAST
}

\section{Justice, truth and oral history: legislating the past 'from below' in Northern Ireland}

McEvoy, K., \& Bryson, A. (2016). Justice, truth and oral history: legislating the past 'from below' in Northern Ireland. Northern Ireland Legal Quarterly, 67(1), 67-90. https://doi.org/10.53386/nilq.v67i1.96

\section{Published in:}

Northern Ireland Legal Quarterly

Document Version:

Publisher's PDF, also known as Version of record

Queen's University Belfast - Research Portal:

Link to publication record in Queen's University Belfast Research Portal

Publisher rights

○ 2016 Northern Ireland Legal Quarterly

\section{General rights}

Copyright for the publications made accessible via the Queen's University Belfast Research Portal is retained by the author(s) and / or other copyright owners and it is a condition of accessing these publications that users recognise and abide by the legal requirements associated with these rights.

Take down policy

The Research Portal is Queen's institutional repository that provides access to Queen's research output. Every effort has been made to ensure that content in the Research Portal does not infringe any person's rights, or applicable UK laws. If you discover content in the Research Portal that you believe breaches copyright or violates any law, please contact openaccess@qub.ac.uk. 


\title{
Justice, truth and oral history: legislating the past 'from below' in Northern Ireland \\ KieRAn McEvoy and AnNa Bryson ${ }^{1}$ \\ Queen's University Belfast
}

\begin{abstract}
Drawing on the 'from below' perspective which has emerged in transitional justice scholarship and practice over the past two decades, this article critically examines the dealing with the past debate in Northern Ireland. The paper begins by offering an outline of the from below perspective in the context of post-conflict or post-authoritarian societies which are struggling to come to terms with past violence and human rights abuses. Having provided some of the legal and political background to the most recent efforts to deal with the past in Northern Ireland, it then critically examines the relevant past-related provisions of the Stormont House Agreement, namely the institutions which are designed to facilitate 'justice', truth recovery and the establishment of an Oral History Archive. Drawing from the political science and social movement literature on lobbying and the ways in which interests groups may seek to influence policy, the paper then explores the efforts of the authors and others to contribute to the broader public debate, including through drafting and circulating a 'Model Bill' on dealing with the past (reproduced elsewhere in this issue) as a counterweight to the legislation which is required from the British government to implement the Stormont House Agreement. The authors argue that the combination of technical capacity, grass-roots credibility and 'international-savvy' local solutions offers a framework for praxis from below in other contexts where activists are struggling to extend ownership of transitional justice beyond political elites.
\end{abstract}

Keywords: transitional justice; from below; dealing with the past; legislation; truth recovery; prosecutions; oral history.

\section{Introduction}

While transitional justice has only emerged as a recognisable field of inquiry in the last two to three decades, it has rapidly acquired all of the elements of what Picard $^{2}$ has termed 'respectabilisation'. Originally viewed by many as an addendum to the study of

1 The authors would like to acknowledge the support of the Arts and Humanities Council which funded the work on which this research is based (Grant Reference AH/J013897/1), the ESRC (Grant Reference ES/J009849/1) from which some of the international comparative work is drawn, as well as the Queen's University Belfast Business Alliance Fund. In addition, we would like to thank our colleagues who worked on the Model Bill process with us, in particular, Brian Gormally, Jeremy Hill, Daniel Holder, Louise Mallinder, Gemma McKeown and our parliamentary draftsman Daniel Greenberg.

2 Emmanuelle Picard, 'Une Discipline en Voie de Respectabilisation: La Germanistique Française au Milieu du XXe Siècle’ (2002) Lendemains 68-78. 
transition within political science, ${ }^{3}$ analysis of the variants of justice which are linked to the shift from conflict or authoritarian rule has become a growth industry. Academics and activists from fields as diverse as law, anthropology, international relations, philosophy, criminology, psychology, history and many others self-identify as doing transitional justice. As one of the authors has argued elsewhere, there is now something of a 'swagger' to the field, not least because of the huge amount of monies spent on 'top-down' transitional justice institutions. ${ }^{4}$ For example, retributive-focused legal institutions, such as the International Criminal Tribunal for the Former Yugoslavia, the International Criminal Tribunal for Rwanda, the International Criminal Court, or hybrid tribunals in Sierra Leone, East Timor or Cambodia, have spent billions of dollars in efforts to prosecute those deemed most responsible for past human rights violations. ${ }^{5}$ The term 'truth commission' is now widely understood and utilised in everyday language and politics, including in longestablished democracies. ${ }^{6}$ Similarly, 'rule of law' programmes are now a major constituent element of democratic reform and peace-building work - again buttressed by huge amounts of funding from the international donor community. ${ }^{7}$ Dealing with the past in the guise of transitional justice is now normalised, mainstreamed and increasingly institutionalised.

In tandem with that institutionalisation of transitional justice, for at least a decade, a number of scholars and activists in different transitional societies have been pressing for a greater openness to what McEvoy and others have termed 'transitional justice from below'. ${ }^{2}$ The impetus for such a focus has come from a number of places. Intellectually, it draws from a range of fields (including history, political science, development studies and critical legal studies) which variously emphasise 'from below', 'the subaltern', 'actororientated', 'grass-roots' or legal-pluralist understandings of the intersection between politics, governance and law. ${ }^{9}$ It also reflects a critical approach to whether political elites in some transitional contexts have either the capacity or political will to come to terms with uncomfortable truths about the past. ${ }^{10}$ Given the perhaps inevitable focus on 'the

3 Samuel P Huntington, The Third Wave: Democratization in the Late Twentieth Century (first published University of Oklahoma Press 1991).

4 Kieran McEvoy and Lorna McGregor, 'Transitional Justice from Below: An Agenda for Research, Policy and Praxis' in Kieran McEvoy and Lorna McGregor (eds), Transitional Justice from Below: Grassroots Activism and the Struggle for Change (Hart 2008) 2.

5 William Schabas, Unimaginable Atrocities: Justice, Politics, and Rights at the War Crimes Tribunals (OUP 2012); Phillipe Sands, From Nuremberg to The Hague: The Future of International Criminal Justice (CUP 2003).

6 See Priscilla Hayner, Unspeakable Truths: Transitional Justice and the Challenge of Truth Commissions 2nd edn (Routledge 2011). For example, on 2 March 2009 the New York Times ran an editorial posing the question 'A Truth Commission for the Bush Era?' with regard to the actions of US forces during the 'War on Terror'. President Obama ultimately concluded that such a commission should not be established. See No Truth Commission on Torture, says Obama' Irish Times (Dublin, 25 April 2009).

7 Christopher May, The Rule of Law: The Common Sense of Global Politics (Edward Elgar 2014).

8 See Kieran McEvoy, 'Beyond Legalism: Towards a Thicker Understanding of Transitional Justice' (2007) 34(4) Journal of Law and Society 411-40.

9 See, for example, David Ludden (ed), Reading Subaltern Studies: Critical History, Contested Meaning and the Globalization of South Asia (Anthem Press 2002); E P Thompson, The Making of the English Working Class (first published Victor Gollancz 1963); Jeremy Brecher, Tim Costello and Brendan Smyth, Globalisation From Below: The Power of Solidarity (Southend Press 2001); Jean-Paul Faguet, Decentralization and Popular Democracy: Governance From Below in Bolivia (University of Michigan Press 2012); Norman Long, 'The Case for an Actor Orientated Sociology of Development' in Norman Long (ed), Development Sociology: Actor Perspectives (Taylor \& Francis 2001); Sally Engle Merry, Colonizing Hawai'i: The Cultural Power of Law (Princeton University Press 2000).

10 Alexander Betts, 'Should Approaches to Post-conflict Justice and Reconciliation Be Determined Globally, Nationally or Locally?' (2005) 17(5) European Journal of Development Research 735-52; Paul Gready, 'Reconceptualising Transitional Justice: Embedded and Distanced Justice' (2005) 5(1) Conflict, Security and Development 3-21. 
rule of law' as a bedrock of transitional justice, there is often a wariness of the dominance of lawyers and legalism and a related unease that those who have been most affected by violence or human rights abuses often find that their views are not heard or accorded adequate weight once the wheels of 'top-down' transitional justice processes begin to turn. ${ }^{11}$ Indeed, in contexts where national justice systems are themselves too corrupt, tainted, ineffective, or overwhelmed, it is frequently victims and survivor groups, community and civil society organisations, human rights non-governmental organisations (NGOs), church bodies and others that have done much of the heavy lifting in pressing for change and finding alternative or interim means of dealing with the past. ${ }^{12}$

Transitional justice from below does not simply mean locating transitional justice at community level. Rather, the term is increasingly used to denote the 'resistant', 'corrective' or 'mobilising' character of the actions of community, civil society and other non-state actors in challenging hegemonic understandings of the world or seeking to ameliorate the consequences for vulnerable people of the exercise of power by elite political, social or economic actors. ${ }^{13}$ It should also be stressed that, while the from below perspective is generally interested in maximising community ownership and participation in processes of justice in transition, this is not at the expense of a suspension of critical faculties. It certainly does not presuppose a naive or overly romanticised notion of community or civil society as a place that is devoid of reactionary or exclusionary views or practices. ${ }^{14}$ Rather, it requires a cold-eyed and pragmatic assessment of community risks and capacities, and the development of strategies which can buttress against those risks and enhance capacity.

Finally, transitional justice 'from below' is not a rejectionist discourse with regard to equivalent efforts 'from above'. For current purposes, developing effective methods of dealing with the past in transitional contexts is marked not simply through the negotiations between governments and political parties. Rather it requires, imaginative ways of ensuring meaningful engagement in the design and implementation of institutions by those who have been involved in the social and political struggles which placed them on the political agenda in the first place. ${ }^{15}$ It is designed to offer, in Falk's terms, a different vantage point to 'see' more clearly how interactions, accommodations and relationships with institutions and structures from above should evolve. It is therefore intended to encourage and challenge those who design and implement such institutions to improve what they do, to think more deeply about why they do it, and to explore ways in which those same institutions of transitional justice can broaden the participation of those who have been most directly affected by conflict.

The particular 'from below' initiative discussed in this article concerns efforts by the authors and others to inform ongoing political and social discussions on dealing with the past in Northern Ireland. In section one of this article we offer a brief overview of the legal and political context in which this and a related series of interventions on the past have developed over the past few years. We then critically assess some of the basic elements of the most recent attempt to design inter-related processes that might facilitate

11 McEvoy and McGregor (n 4); Nicola Palmer, Courts in Conflict: Interpreting the Layers of Justice in Post-Genocide Rwanda (OUP 2015); Phil Clark, The Gacaca Courts and Post-Genocide Justice and Reconciliation in Rwanda: Justice without Lanyers (CUP 2010).

12 Naomi Roht-Arriaza and Javier Mariezcurrena (eds), Transitional Justice in the Twenty-First Century: Beyond Truth versus Justice (CUP 2006).

13 See, for example, Richard Falk, 'Globalization-from-Below: An Innovative Politics of Resistance' in Richard Sandbrook (ed), Civilizing Globalization: A Survival Guide (State University of New York Press 2003).

14 Amitai Etzioni, The Spirit of Community (Simon \& Schuster 1994).

15 Upendra Baxi, The Future of Human Rights (OUP 2002). 
prosecutions, truth or information recovery and the creation of an oral archive processes which are reflected in the proposed institutions enshrined in the Stormont House Agreement (SHA) (2014). Finally, we reflect on our methods and seek to draw out some broader lessons which may be applicable in other transitional contexts where civil society or academics seek to make practical interventions.

\section{The political and legal context to dealing with the past}

The Good Friday Agreement (1998) contained a range of what might be termed 'pastfacing' provisions concerning support for victims, prisoner release and reintegration, policing, human rights and criminal justice reform. ${ }^{16}$ However, unlike similar peace accords elsewhere, there was no overarching mechanism such as a truth and reconciliation commission designed to comprehensively 'deal with the past'. Instead, a 'piecemeal' approach has given rise to a smorgasbord of institutions and techniques to deal with particular aspects of the conflict and its consequences. These have included: the establishment of a number of public inquiries into particular controversial events, including the killing of 13 civilians on Bloody Sunday; ${ }^{17}$ the establishment of the Office of the Police Ombudsman, the responsibilities of which include investigating both historical and contemporary allegations of police malfeasance; ${ }^{18}$ a series of coronial inquests into over 50 conflict-related deaths, many of which occurred in controversial circumstances; ${ }^{19}$ the establishment and ultimate disbandment of the Historical Enquiries Team (HET), a police-led review of all conflict-related deaths; ${ }^{20}$ a series of high-profile litigation efforts by affected families in the domestic courts and the European Court of Human Rights; ${ }^{21}$ investigations of alleged miscarriages of justice by the Criminal Cases Review Commission; 22 as well as numerous community and civil society-based efforts focused on truth recovery, story-telling, oral history and commemoration. ${ }^{23}$

In addition, there have been at least four major attempts to draw on these incremental efforts and 'pull it all together' in an overarching mechanism or series of mechanisms. The latest initiative is outlined in detail below, but it might be useful at this juncture to offer a brief summary of what is now quite a complex historical narrative, not least

16 For an overview of these and other elements of the Good Friday Agreement, see special issue of Fordham International Law Journal (1998) 22(4).

17 See The Report of the Bloody Sunday Inquiry (Saville Report) HC 29-I vols 1-10 (HMSO 2010).

18 For an overview of the work of the Police Ombudsman, see the most recent annual report: <www.policeombudsman.org/About-Us/Publications/Annual-Reports-and-Business-Plans> accessed 14 March 2016. For the broader context see Graham Ellison, 'A Blueprint for Democratic Policing Anywhere in the World? Police Reform, Political Transition, and Conflict Resolution in Northern Ireland' (2007) 10(3) Police Quarterly 243-269.

19 See speech by the Lord Chief Justice Sir Declan Morgan, 'Review of the Strategy for Victims and Survivors', Victims and Survivor Commission Conference, Belfast, 9 March 2016.

20 See Patricia Lundy, 'Can the Past be Policed?: Lessons from the Historical Enquiries Team Northern Ireland' (2009) 11 Journal of Law and Social Challenges 109-56; 'Exploring Home-Grown Transitional Justice and its Dilemmas: A Case Study of the Historical Enquiries Team Northern Ireland' (2009) 3 International Journal of Transitional Justice 321-40.

21 Gordon Anthony and Luke Moffett, 'Northern Ireland Law, Politics and the "Problem of the Past" (2014) 20(3) European Public Law 395-406.

22 Hannah Quirk, 'Don't Mention the War: The Court of Appeal, the Criminal Cases Review Commission and Dealing with the Past in Northern Ireland' (2013) 76(6) Modern Law Review 949-80.

23 See, for example, Brian Gormally and Kieran McEvoy, Dealing with the Past in Northern Ireland From Below' (Community Foundation for Northern Ireland 2009); Kirk Simpson, Truth Recovery in Northern Ireland: Critically Interpreting the Past (Manchester University Press 2013); Grainne Kelly, 'Storytelling' Audit: An Audit of Personal Story, Narrative and Testimony Initiatives Related to the Conflict in and about Northern Ireland (Healing Through Remembering 2005). 
because what is currently under consideration has drawn explicitly and implicitly from previous work.

In 2006, following a two-year process of extensive debate and deliberation with a diverse cross-section of opinion, the local NGO, Healing Through Remembering, produced a major report which outlined a series of options for dealing with the past. ${ }^{24}$ In 2007, following consultation with the Irish government, the then Labour administration appointed the Consultative Group on the Past (CGP) to make recommendations on how to deal with the past. The British and Irish governments were very aware of, and directed the CGP towards, the Healing Through Remembering work on the past in its deliberations. ${ }^{25}$ The CGP itself made clear from the outset that it would draw upon this previous work. As the co-chairs Lord Eames and Dennis Bradley told the Irish News early in their consultation process, 'organisations such as Healing Through Remembering have already completed in-depth analysis across a range of issues on dealing with the past. When you take this along with the efforts of local initiatives undertaken by community organisations, it is clear that there is an opportunity to build on that work. ${ }^{26}$ Similarly, once its report was completed, the CGP was always candid that it had not 'started from scratch' in conducting its work. ${ }^{27}$ Indeed, the antecedence of some of the key elements of the CGP report became a focus for both supporters and detractors, once its recommendations were made. ${ }^{28}$

Following widespread controversy concerning one recommendation that all victims of the conflict (including the family members of paramilitaries who were killed) should receive a $f_{12,000}$ recognition payment, that report was rejected by the Conservative-led Coalition government which came to power in 2010. Three years later, US diplomats Richard Haass and Megan O’Sullivan chaired negotiations involving the political parties

24 Kieran McEvoy, Making Peace with the Past: Options for Dealing with the Past in and about Northern Ireland (Healing Through Remembering 2006).

25 As Minister of State at the Department of the Taoiseach (Deputy Tom Kitt) told the Dáil, I commend to the House the work of Healing Through Remembering, a cross-community organisation bringing together representatives from North and South and Britain, of victims' groups, churches, academics, community and youth organisations. They have produced reports and recommendations on issues including truth recovery, commemoration, acknowledgement and story telling. These are thoughtful and well-researched documents that deserve careful consideration. They would serve as a very useful reference for the work of the Consultative Group On The Past.’ Dáil Éireann Deb, 31 January 2008, vol 645, col 730.

26 'Dealing with the Troubled Past is Difficult Issue for Society' Irish News (Belfast, 2 January 2008).

27 'The report took account of existing work and research undertaken into ways of dealing with the past by a large range of individuals, groups, non-governmental organisations, statutory bodies and Governments. The Consultative Group paid particular respect to the work of Healing Through Remembering (HTR), a crosscommunity project made up of individual members from a range of political backgrounds.' See 'Report of the Consultative Group on the Past in Northern Ireland', second report of session 2009-10, House of Commons Northern Ireland Affairs Committee, 6.

28 For example, Alliance Party spokesperson Stephen Farry stated: 'We fully appreciate and welcome the Eames Bradley Report ... a lot of the elements within Eames/Bradley have been trailed, for example, through Healing Through Remembering, such as storytelling, addressing the needs of victims, memorials, Day of Reflection, broader reconciliation issues.' Speech at 'Reflecting on the Report of the Consultative Group on the Past Conference', Belfast, 15 May 2009. On the other hand, in dismissing the CGP report, the prominent Unionist victim campaigner Willie Frazer argued in a blog titled 'Eames Bradley Quango' that: 'The naive nonsense that exists at the core of this report found its origins in the Healing Through Remembering work which was rejected by victims. Its answer adopted by Eames Bradley is to rely on the decency of terrorists to come forward and tell the truth, indeed the appeasement does not end there they will be paid for their participation - given immunity from prosecution. This is clearly a rehash of Republican wish lists, South African fairy tales and the wilder nonsense from the minds of Northern Ireland great and good. But as victims we say it is unacceptable, it is not worth the paper it is written on.' William Frazer, 20 October 2008 <www.cain.ulst.ac.uk/victims/archive/author.html> accessed 13 February 2016. 
in Northern Ireland which focused on a number of outstanding issues, including dealing with the past. Despite the negotiation of seven successive drafts, the parties ultimately failed to reach an agreement on the past and other matters and in December 2013 the talks were terminated as no agreement could be reached.

In September 2014, negotiations recommenced, this time with both the British and Irish governments more centrally involved. In December 2014, the SHA was published, which included provisions to establish a number of mechanisms designed to deal with the past (detailed below). In the subsequent Queen's speech, the UK government committed to introducing legislation at Westminster to enact these commitments. ${ }^{29}$ In 2015 , relations within the Northern Ireland Executive deteriorated over a number of issues, including welfare reform, as well as austerity cuts and confirmation by the Police Service of Northern Ireland (PSNI) that the IRA still existed following the murder of two senior Republicans in Belfast. ${ }^{30}$ Political negotiations recommenced in September 2015 between the two governments and the five political parties in the Northern Ireland Executive and eventually, in November 2015, the Fresh Start Agreement was reached. ${ }^{31}$ However, while substantial progress was apparently made, ${ }^{32}$ no agreement on dealing with the past was reached during these negotiations, much to the dismay of victims across the political spectrum. ${ }^{33}$ In the run-up to the negotiations, the British government published a 'summary of measures document' offering a broad outline of its plans and a draft government Bill on the past was prepared. ${ }^{34}$ A leaked version of the government's draft Bill (which was amended during the negotiations) contained extensive provision for the British government to redact information deemed 'sensitive' from going to families affected by the conflict on the basis of national security (discussed further below). This ultimately proved unacceptable to both of the nationalist parties (Sinn Féin and the Social Democratic and Labour Party (SDLP)) and the Irish government. ${ }^{35}$ At the time of writing, efforts are ongoing (including by the authors and others) to seek to narrow the gap between the different actors on the outstanding issues preventing the establishment

29 'Legislation will be Taken Forward Giving Effect to the Stormont House Agreement in Northern Ireland', Queen's Speech, 27 May 2015 <www.gov.uk/government/speeches/queens-speech-2015> accessed 14 February 2016.

30 'IRA “Army Council” Still Exists but Has “Wholly Political Focus”, BBC NI News, 20 October 2015.

31 'A Fresh Start: The Stormont Agreement and Implementation Plan: an Agreement to Consolidate the Peace, Secure Stability, Enable Progress and Offer Hope', 17 November 2015 <www.gov.uk/government/news/afresh-start-for-northern-ireland $>$ accessed 15 March 2016.

32 The cross-party talks that ran from 8 September to 17 November last year, which culminated in the Fresh Start agreement, brought us closer than ever before to consensus on the best way to deal with Northern Ireland's past. While we established much common ground, it was not possible to reach agreement on all issues ... The UK Government is determined to resolve the outstanding issues that are preventing the establishment of the legacy institutions set out in the Stormont House Agreement.' Written Statement from Secretary of State for Northern Ireland to Parliament, 21 January 2016 <www.gov.uk/government/speeches/written-ministerial-statement-on-the-icir> accessed 13 March 2016.

33 See, for example, 'Stormont Deal: Cross-Community Victims Group Accuses Political Leaders of Betrayal' Newsletter (Belfast, 18 November 2015); 'Where is rhe Fresh Start for Victims, Leaders Asked' Irish News (Belfast, 19 November 2015).

34 'Northern Ireland (Stormont House Agreement) Bill 2015 Summary of Measures' $<$ www.gov.uk/government/publications/villiers-publishes-policy-paper-on-northern-ireland-stormonthouse-agreement-bill-2015> accessed 2 March 2016.

35 'Britain Fails to Honour its Commitment on Truth and Justice' An Phoblacht (Dublin, 1 December 2016); Mark Durkan, 'National Security Strictures Suppress Truth about Dirty War' Derry Journal (Derry, 26 November 2015); 'Charlie Flanagan Critical of National Security "Smothering blanket”' Irish News (Belfast, 27 November 2015). 
of the various past-focused mechanisms, including a workable mechanism for dealing with the issue of redactions in the interest of national security.

As noted above, the provisions on the past contained in the SHA are in reality a sort of palimpsest which draws upon the various proposals which have come before. As one seasoned political commentator who has followed closely the twists and turns of the debate on the past for over a decade told one of the authors in 2015: 'there are only so many ways of doing this thing and God knows we have explored them all since the Healing Through Remembering report came out in 2006'.36 The SHA commits the two governments and the five parties in the Northern Ireland Executive to establishing four mechanisms. These are as follows.

- Historical Investigations Unit (HIU) - an independent investigative institution (answerable to the Policing Board of Northern Ireland) which will take over the past-focused work previously undertaken by the HET and the Office of the Police Ombudsman. This body is envisaged as having the equivalent powers of the PSNI in terms of arrest, stop, search, question, retaining evidence and so forth. Decisions regarding whether or not sufficient evidence is available for a prosecution for conflict-related offences will be made by the Director of Public Prosecutions. It is required to carry out investigations which are deemed compatible with the Article 2 requirements of the European Convention on Human Rights. ${ }^{37}$ In addition, where there is sufficient evidence to meet the possible threshold for prosecution, the Director of Public Prosecutions shall make that decision. In addition, the HIU is required to produce a 'victim-centred' report to the affected families in the case of each of the deaths that it investigates. ${ }^{38}$

- Independent Commission on Information Retrieval (ICIR) - an independent international body established by treaty by the UK and Irish government. The ICIR will have an independent chair of international standing, as well as one other nominee each appointed by the British and Irish governments and the First and Deputy First Ministers. The function of this body is to allow families affected by the conflict to seek and receive information about the circumstances surrounding the death of their loved ones from those who may have knowledge of these events. In order to facilitate those with such information coming forward, the SHA specifies that no information provided can be used for criminal or civil proceedings. Both governments commit to supporting any request for information from the ICIR and its operation shall be held accountable to the principles of independence, rigour, fairness and balance, transparency and proportionality'. 39

- Oral History Archive (OHA) - this element was described in the SHA as providing 'a central place for people from all backgrounds (and from throughout the UK and Ireland) to share experiences and narratives related to the Troubles'. The SHA also stipulated that, as well as collecting new archival material, the OHA would 'attempt to draw together and work with

36 Personal interview with prominent journalist, 21 October 2015.

37 Anthony and Moffett (n 21).

38 SHA (2014), para 30 <www.gov.uk/government/publications/the-stormont-house-agreement> accessed 10 February 2016.

39 Ibid paras 41-50. 
existing oral history projects'. It crucially noted that: 'The Archive will be independent and free from political interference.' In the subsequent leaked draft legislation and accompanying policy document, the British government specified that the OHA would be located within the Public Records Office of Northern Ireland (PRONI), albeit with 'operational independence' from the Department of Culture Arts and Leisure, the relevant parent department. ${ }^{40}$

- Implementation and Reconciliation Group (IRG) - the work of the IRG will include determining a range of themes and patterns related to the conflict which shall be explored by a group of appointed academic experts. ${ }^{41}$ The work of those academics will be overseen by a group of political nominees, with the Democratic Unionist Party (DUP) appointing three members, Sinn Féin two, and the other parties which were signatories to the Agreement appointing one each, as would the two governments - with an independent chair of international standing. The Agreement stipulates that the work of the IRG 'should be conducted with sensitivity and rigorous intellectual integrity, devoid of any political interference'. The process is designed to 'promote reconciliation' and a 'better understanding of the past' and 'reduce sectarianism'. It also states that: 'In the context of the work of the IRG the UK and Irish Governments will consider statements of acknowledgement and would expect others to do the same.' 42

While reaching an agreement to establish these four institutions represented a significant political achievement, the brevity of the relevant text was such that much of the ensuing discussion inevitably centred on the detail of the enabling legislation. Not for the first time, 'progress' had depended on a measure of creative ambiguity. As one of the senior party political negotiations told the authors, '. . in reality all we could achieve in the end were heads of agreement'. ${ }^{43}$ Given that reality, the legislative detail was inevitably going to be a source for additional debate and discussion amongst politicians and civil society once negotiations recommenced in the autumn of 2015. It was in order to ensure that the relevant political and public conversations on these often technical matters were as informed as possible that the authors were involved with other colleagues in producing the Model Bill on the past. That Model Bill and accompanying explanatory text are detailed elsewhere in this issue. Before critically examining some of the substantive measures contained both in the leaked government legislation which appeared in 2015 and the Model Bill, it might be useful at this juncture to offer some background to the process by which the Model Bill was produced.

For a number of years, McEvoy has been working closely with different civil society organisations on aspects of dealing with the past in Northern Ireland, most notably Healing Through Remembering and the Committee on the Administration of Justice. In addition, with Mallinder and others, he has also conducted extensive international and comparative research to explore how different jurisdictions have dealt with challenging

40 SHA (n 38) paras 22-25.

41 Ibid para 51.

42 Ibid paras 52-54.

43 Discussion with senior political negotiator, 30 January 2015. By way of illustration: the Healing Through Remembering Report (2006) on options for dealing with the past was 117 pages; the report of the CGP (2009) contained 189 pages including appendices; the Haass-O'Sullivan (2013) document contained 19 pages on the past; and the SHA had only five pages on the same topic. 
aspects of the transition from conflict or authoritarianism. ${ }^{44}$ That international research on the legal and political challenges associated with dealing with the past fed directly into the local work in Northern Ireland.

Commencing in 2011, he led a team of academics, lawyers and activists who (in partnership with Healing Through Remembering) began an Arts and Humanities Research Council-funded project designed to assist politicians, government officials, civil society groups and others in exploring the complex interplay between prosecutions, amnesties (and related immunities) and truth recovery in Northern Ireland. That project engaged in an extensive range of bilateral meetings with victims groups, ex-prisoners, former police officers and others, as well as the British and Irish governments and all of the political parties involved in the negotiations on the past. The team offered to provide accurate but accessible legal and policy advice (free of charge) to any relevant civil society or political party interested in the dealing with the past debate. As a result, the team produced a series of five reports, as well as several blogs, organised a number of conferences and seminars, and published the findings in numerous broadcast and print media outlets. ${ }^{45}$

As the original funding came to an end in 2013, additional resources were secured from the Queen's University Business Alliance to support a partnership on dealing with the past with Northern Ireland's primary human rights NGO, the Committee on the Administration of Justice (CAJ). In 2015 CAJ launched its Apparatus of Impunity report (funded by the Business Alliance) which documented many of the failings of the 'piecemeal' approach to the past. In an effort to move beyond critiquing the status quo, McEvoy and Bryson from Queen's, colleagues from CAJ, along with Mallinder and another colleague (Hill) from the Transitional Justice Institute, ${ }^{46}$ instructed parliamentary counsel (Greenberg) and began work on producing the Model Bill on dealing with the past and the accompanying explanatory commentary (reproduced elsewhere in this issue). From 2014 onwards the developing drafts were discussed in the course of more than 20 detailed face-to-face meetings with senior British and Irish officials (involved in both the political negotiations and the preparation of their respective legislation in either jurisdiction on the past), ${ }^{47}$ senior politicians from across the political spectrum and a wide range of local civil society organisations. Drafts of the Bill were also presented at three major conferences organised in association with our civil society partners and the Northern Ireland Commission for Victims and Survivors.

Once completed, the Model Bill was formally launched at an event at the House of Lords sponsored by former Northern Ireland Office Minister Lord Dubbs in October 2015 and addressed by Shadow Northern Ireland Secretary of State Vernon Coker, amongst others. It was also widely publicised through the local print and broadcast media, at a further conference in Belfast, and a range of seminars and briefings aimed at civil society organisations and political parties.

44 See, for example, Kieran McEvoy, 'Prisoner Release and Conflict Resolution: International Lessons for Northern Ireland' (1998) 8(1) International Criminal Justice Review 33-61; Kieran McEvoy and Louise Mallinder, 'Amnesties in Transition: Punishment, Restoration, and the Governance of Mercy' (2012) 39(3) Journal of Law and Society 410-40; Kieran McEvoy and Kirsten McConnachie, 'Victims and Transitional Justice Voice, Agency and Blame' (2013) 22(4) Social and Legal Studies 489-513.

45 The reports, blogs etc. are all available on the project website <www.amnesties-prosecution-publicinterest.co.uk> accessed 14 March 2016.

46 Jeremy Hill is now a visiting scholar at the Transitional Justice Institute. He is a former senior Foreign and Commonwealth Office lawyer, a former UK ambassador and served as the legal advisor to the CGP.

47 A number of the past-focused institutions proposed in the SHA required parallel enabling legislation in both Westminster and Dáil Éireann. 
Our approach in drafting and disseminating the Model Bill was to stick closely to the text of the SHA and to write the substantive sections in a manner that was consistent with UK domestic law and the relevant international human rights standards. The Model Bill was very explicitly not a 'wish list' document. From the outset, we were very aware that its efficacy as an advocacy tool depended upon its technical competence and our collective credibility in delivering it, and related policy outputs, in as measured, constructive and informed a fashion as possible. ${ }^{48}$ The detailed explanations of the text in the Model Bill are outlined in the 'Clause by clause' article published elsewhere in this issue. In this paper we have attempted to place the work on the Model Bill in its broader legal and political context. In particular, we will now examine how those involved sought: to frame discussions on the workability of the various mechanisms proposed in the SHA in the light of past experiences of analogous institutions both locally and internationally; to manage the expectations of affected parties, in particular victims of the conflict; and to have a close eye on what would be required politically to maximise public confidence in the institutions. Below, we have grouped the primary issues around which the efforts to deal with the past in Northern Ireland have coalesced - namely, the potential for conflict-related prosecutions; the opportunities for truth or information recovery (both about specific events and broader patterns and themes of the conflict); and the role of archives and story-telling in capturing people's lived experiences during the conflict.

\section{Prosecutions, 'justice' and disclosure}

In many transitional contexts, the struggle for 'justice' is often viewed as synonymous with the efforts to investigate and prosecute those who were responsible for previous acts of murder, torture and other human rights violations. The importance of individual accountability, deterrence, bringing some 'satisfaction' to victims, embedding human rights and the rule of law and symbolic marking of the wrongness of past actions are amongst the compelling rationales offered for pursuing past prosecutions. ${ }^{49}$ In the Northern Ireland context, a determination to retain the possibility of prosecutions for conflict-related offences has been a constant theme in political negotiations on dealing with the past - usually expressed most strongly by the Unionist political parties and victims' groups from that community. ${ }^{50}$ The political reality is that the 'focus on dealing with the past is ensuring robust criminal prosecutions are in place to pursue justice' has been a fundamental prerequisite for Unionist negotiators throughout the transition. ${ }^{51}$ The

48 For a discussion on the relationship between credibility and effective advocacy, see Bertram J Levine, The Art of Lobbying: Building Trust and Selling Policy (CQ Press 2008); John C Scott, The Social Process of Lobbying (Routledge 2014).

49 Kathryn Sikkink, The Justice Cascade: How Human Rights Prosecutions are Changing World Politics (WW Norton 2011).

50 Cheryl Lawther, Truth, Denial and Transition; Northern Ireland and the Contested Past (Routledge 2013).

51 DUP MP Jeffrey Donaldson, 'Final Furlough Approaching in Haass Talks' Newsletter (Belfast, 14 December 2013). The SDLP and to a lesser extent Sinn Féin have also continued to advocate for prosecutions of state actors such as those involved in the killings at Bloody Sunday. On the announcement that a murder investigation into the Bloody Sunday killings would restart, Sinn Féin Assembly Member, Raymond McCartney, called for the investigation to be properly resourced 'to ensure the relatives get access to justice' Irish Republican News (Dublin, 10 January 2015). Responding to the arrest of an ex-Lance Corporal from the Parachute Regiment as part of that investigation, Derry SDLP councillor, Brian Tierney, stated: 'I want to welcome the progress made in the investigation into the murder of 14 innocent civilians in Derry on Bloody Sunday. The families of those murdered by British soldiers on that day in 1972 waited far too long for the truth about what happened, they should not be forced to wait any longer for justice.' Belfast Media Group (Belfast, 11 November 2015). 
vehicle for achieving that objective has been the police-led work of the HET and its successor envisaged under the SHA, the HIU.

Informed by the political reality that 'the justice option' had to be kept on the table, much of our policy and practical work interventions on the issue have been directed towards helping to manage the expectations of victims regarding the potential for conflict-related convictions. In the policing and legal community, there is a widespread acceptance that the very significant practical and evidential challenges associated with securing convictions for historical offences (many of which happened decades ago) mean that very few convictions will in reality be secured. ${ }^{52}$ Indeed, since the signing of the Good Friday Agreement in 1998 there have only been four successful prosecutions of non-state actors (two Loyalist and two Republican) for pre-1998 conflict-related murders or attempted murders and none of state actors. ${ }^{53}$ Moreover, under the terms of the Good Friday Agreement, anyone convicted of a conflict-related offence will serve a maximum of two years regardless of the seriousness of the offence. ${ }^{54}$ Thus, our approach to working on the HIU has been to ensure that these realities remain at the forefront of the public conversation while simultaneously emphasising the truth recovery potential of the proposed mechanism.

When the HET was established it had a number of specified objectives to guide its work. Interestingly, the first of the three specified objectives of the HET was to 'assist in bringing a measure of resolution' to the families of victims killed during the conflict between 1968 and 1998. 55 The key output designed to deliver this measure of resolution was the Review Summary Report about the circumstances of the death of their loved one delivered to families. Mindful of legal and ethical responsibilities, ${ }^{56}$ the HET committed to a policy of 'maximum permissible disclosure, consistent with legal constraints'. ${ }^{57}$ For the vast majority of cases reviewed by the HET (and if the SHA is implemented, its successor, the HIU), it is these reports to families which will be the most important product of the work of those investigations.

As is discussed in more detail in the 'Clause by clause' article, we considered that the key elements to maximise the effectiveness of the HIU to deliver such products were to

52 As former Chief Constable Sir Hugh Orde said with regard to the HET which he established: ‘. . . the likelihood of solving cases was clearly going to be slight. Witnesses would be old or dead. Exhibits, if still available, could be contaminated or inadmissible. Informants and agents would be in the mix; the original paperwork incomplete or missing ... At the height of the Troubles, 497 people were murdered in one year. The forensic laboratory was blown up twice. Numerous police stations were blown up, stations housing much of the investigative material. Police resources, understandably, would have been stretched to the limit.' Hugh Orde, 'War is Easy. Peace is the Difficult Prize', Longford Lecture, 2 December 2009. In a similar vein, the Attorney General for Northern Ireland, John Larkin, noted: 'More than 15 years have passed since the Belfast Agreement, there have been very few prosecutions, and every competent criminal lawyer will tell you the prospects of conviction diminish, perhaps exponentially, with each passing year, so we are in a position now where I think we have to take stock.' 'Northern Ireland Attorney General John Larkin Calls for End to Troubles Prosecutions', BBC NI News, 20 November 2013.

53 See 'The Apparatus of Impunity? Human Rights Violations and the Northern Ireland Conflict: A Narrative of Official Limitations on Post-Agreement Investigative Mechanisms' (Committee on the Administration of Justice 2015) ii.

54 Northern Ireland (Sentences) Act, 1998 (s 10, 'Accelerated release').

55 The other specified objectives were to re-examine all 'troubles related' deaths 'in a manner that satisfies the PSNI's obligation to conduct an effective investigation' and to do so in a way that commands the confidence of the wider public. PSNI HET Operational Guide 2013, para 2:1.

56 For example, the Regulation of Investigatory Powers Act 2000 which makes it a criminal offence to name an informant and contains obligations to protect lives under Article 2 European Convention on Human Rights.

57 See Lundy (n 20). 
ensure that it is independent, properly resourced, suitably staffed (including with reference to gender) and sufficiently empowered - particularly with regard to the disclosure of documents and other materials. As has been well documented, one of the key failings of the HET when it was in operation was its practical inability to ensure that former members of the Royal Ulster Constabulary (RUC) did not compromise the independence of investigations into historical cases where state malfeasance (including by the RUC) was a constituent part of the investigation. ${ }^{58}$ Our proposed solution to this issue was to adopt a similar position to the Office of the Police Ombudsman regarding legacy cases and to disbar former RUC or British Army members (or indeed those with an affiliation to paramilitary organisations or their linked political parties) from employment by the HIU. On the issue of resourcing, we sought to ensure that the HIU could not be subject to financial manipulation or general austerity measures by specifying that the UK Treasury should determine the HIU's budget and that it must be paid out of the Consolidated Fund - which would mean that in practice its budget could only be changed by a relevant vote in Parliament. With regard to disclosure, the formulation in the Model Bill was that other public authorities had an unfettered duty of disclosure in response to a request by the HIU for documentation requested in conducting its investigations. With regard to the onward disclosure to families by the HIU in the subsequent reports, the Model Bill suggested that the HIU Director may omit information if it might put a person's life at risk or if it might prejudice the administration of justice (e.g. interfere with a potential successful prosecution).

As noted above, this final issue regarding the disclosure powers of the HIU became the key stumbling block which apparently prevented an agreement being reached in late 2014. After political negotiations had recommenced in the autumn of 2015, a leaked version of the government's draft legislation on dealing with the past in Northern Ireland came into the public arena. Amongst the most notable elements of that leaked draft were the provisions relating to disclosure and the HIU. While the powers of disclosure of information including intelligence to the HIU to assist it in conducting investigations were quite strong, the HIU's ability to provide 'onward disclosure' of such information to families was significantly curtailed by numerous references to powers that the Secretary of State could exercise to redact information on 'the grounds of national security' - a term that was not included in the Stormont House Agreement. As noted above, from the outset Sinn Féin and the SDLP (and latterly the Irish government and the Alliance Party) all criticised the British government for attempting to use a 'national security veto' to undermine the truth recovery functions of the HIU. ${ }^{59}$ While none of the political actors have contested the responsibility to redact information that might put individuals' lives at risk (the version favoured in the Model Bill), difficulties in assessing which other

58 Patricia Lundy and Bill Rolston, 'Redress for Past Harms? Official Apologies in Northern Ireland' (2016) 20(1) International Journal of Human Rights 104-22; Patricia Lundy, 'Research Brief: Assessment of the Historical Enquiries Team (HET) Review Processes and Procedures in Royal Military Police (RMP) Investigation Cases' (Ulster University Research Report 2012) <http://eprints.ulster.ac.uk/21809/> accessed 21 March 2016.

59 'Sinn Féin Criticise Leaked Draft Westminster Bill Dealing With Legacy of The Troubles' BBC NI News (Belfast, 6 October 2015); 'Stormont House Agreement: SDLP State Opposition to Victims Bill' Derry Journal (Derry, 14 October 2015); 'Republic's Foreign Minister Charlie Flanagan Critical of National Security Smothering Blanket' Irish News (Belfast, 27 November 2015). The Alliance Party leader and Justice Minister David Ford is quoted as 'sharing the concerns of nationalist and the Irish government' over the national security clauses in the leaked Bill. He told the Irish News, 'Clearly every government has national security issues but the concerns we expressed on seeing the draft bill was that there seemed to be about four layers of that - which gave an indication of an unwillingness to be opened. If I thought there was an overlaying of national security it's not surprising other people rejected it completely.' in 'David Ford Upbeat for Alliance ahead of Stormont Election' Irish News (Belfast, 4 March 2016). 
legitimate national security interests might be redacted and the decision-making process for making such redactions have continued to prove difficult to resolve. Since the political negotiations failed to reach agreement, the authors and other civil society actors have been working through a range of possible solutions. Drawing upon the relevant UK and European Court of Human Rights jurisprudence, and best practice in other transitional justice contexts, we have been examining the criteria by which such redactions could be made, the shape of an independent judicial decision which could determine the reasonableness of any such redactions, and the ways in which the respective interests of the state and affected families might be legally represented in coming to such a determination. ${ }^{60}$ That work is ongoing at the time of writing.

In sum, the drafting of the Model Bill and related policy and research work before and since has sought to engage with the technical challenges associated with legislating for an investigative mechanism which has both a prosecutorial and a truth recovery function. Debates around the meaning and purpose of justice in post-conflict and postauthoritarian contexts are quite commonplace. As the field has evolved, differing shades of emphasis on retributive, restorative, transformative and other iterations of justice often map onto particular institutions such as trials, truth commissions, reparations programmes and so forth. ${ }^{61}$ What is less common, however, is the institutionalisation of both retribution and restorative measures in the same mechanism. The HIU and its predecessor the HET are an adaptation of police 'cold case review' investigative techniques now well established in many settled democracies. However, that adaptation has been applied to a post-conflict context where the mechanism is designed to provide the possibility of both prosecutions and truth recovery and where the state which is designing the mechanism (and, of course, the former police force, the RUC) was a direct protagonist in the conflict. Little wonder that reaching political agreement on the relevant legislation has proved such a formidable challenge.

\section{TRUTH, 'INFORMATION RETRIEVAL' AND IMMUNITY}

In addition to the justice-focused elements to transitional justice, scholarship and praxis in the field has been focused since at least the 1980s on the notion of truth recovery as a key component to dealing with past violence and human rights abuses. ${ }^{62}$ The efforts at truth recovery in a number of Latin-American jurisdictions including Argentina, Chile, Guatemala and others were most famously incorporated into the South-African Truth and Reconciliation Commission (SATRC) established in 1995. ${ }^{63}$ Over 40 truth commissions have been established since the Argentinian Commission on Disappearances was set up in 1983 and variants on the mechanism have emerged in recent years in settings as diverse as Sierra Leone (2000), Canada (2009), Brazil (2011) and Sri Lanka (2015). ${ }^{64}$ The rationales for doing truth recovery usually include: the rights of affected families and survivors to

60 Kieran McEvoy, 'The Stormont House Agreement Model Bill, National Security and Dealing with the Past in Northern Ireland', paper presented at Queen's Human Rights Centre, 14 March 2016.

61 See, for example, Ruti Teitel, Transitional Justice (OUP 2002); Roht-Arriaza and Mariezcurrena (n 12); Kerry Clamp (ed), Restorative Justice in Transition (Routledge, 2013); Paul Gready and Simon Robins, 'From Transitional to Transformative Justice: A New Agenda for Practice' (2014) 8(3) International Journal of Transitional Justice 339-61.

62 Hayner (n 6).

63 Richard A Wilson, The Politics of Truth and Reconciliation in South Africa: Legitimizing the Post-Apartheid State (CUP 2001).

64 Hayner (n 6); International Centre on Transitional Justice, Drafting a Truth Commission Mandate: A Practical Tool (2013); 'Sri Lanka to Set Up a South Africa Style Truth and Reconciliation Commission' The Guardian (London, 15 September 2015). 
know (sometimes referred to as the 'right to truth'); the establishment of an authoritative public record; challenging cultures of denial and impunity; and, particularly since the SATRC institutionalised the linkage, encouraging personal, communal and social reconciliation. ${ }^{65}$ In addition, truth commission or equivalent truth recovery mechanisms are often framed as either an alternative to retributive trials or in some cases as a complementary measure - a recognition that punishing all of those guilty of past atrocities through the courts is often practically impossible. ${ }^{66}$ Each of these elements have featured to varying degrees in the debates on dealing with the past in Northern Ireland.

Much of the truth or truths about the conflict in Northern Ireland which have been revealed to date have come from the various piecemeal mechanisms discussed above. ${ }^{67}$ Amongst the various efforts to devise an overarching approach to the past, one can discern a clear shift in the political language. In the 2006 Healing Through Remembering document, one of the options explored was the establishment of a 'Truth Recovery Commission'. In 2009, the CGP recommended the establishment of a 'Legacy Commission', key tasks of which were to establish truth and 'information recovery'. 68 The CGP further stipulated that the processes of investigation, information recovery with regard to individual cases, and the examination of larger 'themes' in the conflict would come under the purview of the proposed Legacy Commission. ${ }^{69}$ In 2013, the final version of the Haass-O'Sullivan text which ultimately failed to reach agreement included provisions for the establishment of an Independent Commission for Information Retrieval (ICIR) with no mention of a 'truth recovery' function. The Haass-O'Sullivan document also contained a commitment that the ICIR 'will also establish an internal unit to analyse patterns or themes . . . to understand context and contribute to public awareness of history both now and for subsequent generations'. ${ }^{70}$ As noted above, the ICIR was retained in the SHA 'to enable victims and survivors to seek and privately receive information about the (Troubles related) deaths of their next of kin'. ${ }^{71}$ However, in the negotiations which led to the SHA, the 'big picture' analysis was decoupled from the ICIR and that responsibility was given to a new mechanism, the IRG, 'to oversee themes, archives and information recovery'. ${ }^{72}$ The word 'truth' does not appear anywhere in the SHA.

65 Margaret Popkin and Naomi Roht-Arriaza, 'Truth as Justice: Investigations Commissions in Latin America' (1995) 20(1) Law and Social Inquiry 79-116; Erin Daly, 'Truth Skepticism: An Inquiry into the Value of Truth in Times of Transition' (2008) 2(1) International Journal of Transitional Justice 23-41; Marie Breen Smyth, Truth Recovery and Justice after Conflict: Managing Violent Pasts (Routledge 2007).

66 Mark Freeman, Truth Commissions and Procedural Fairness (CUP 2006); Amnesty International, 'Commissioning Justice: Truth Commissions and Criminal Justice' (2010).

67 It should also be noted that a number of prominent community-based truth recovery processes have also been a feature of the Northern Ireland conflict and transition. See further McEvoy (n 24); Patricia Lundy and Mark McGovern 'Whose Justice? Rethinking Transitional Justice from the Bottom Up' (2008) 35(2) Journal of Law and Society 265-92.

68 As the report makes clear, the authors were keen to distinguish their work so that it 'should not be read as a copy of the South African Truth and Reconciliation Commission'. See 'Report of the Consultative Group on the Past, 23 January 2009', 56 <www.cain.ulst.ac.uk/victims/docs/consultative_group/ cgp_230109_report.pdf> accessed 12 January 2016.

69 Ibid 134.

70 Richard Haass and Megan O’Sullivan, 'Proposed Agreement, 31 December 2013: An Agreement Among the Parties of the Northern Ireland Executive' 9 <www.cain.ulst.ac.uk/events/peace/haass-talks/haass_2013-1231.pdf $>$ accessed 12 January 2016.

71 SHA (n 38) para 41.

72 Ibid para 51. 
The lack of emphasis on truth recovery in the evolution of the dealing with the past mechanisms is of interest. Of course, there is a plethora of literature which offers strong critiques of the very notion of truth and highlights the particular challenges of truth recovery in post-conflict contexts where memory wars remain a key political and ideological battleground. ${ }^{73}$ A certain intellectual wariness about the viability of truth recovery in Northern Ireland, as elsewhere, is quite commonplace. More immediate, however, is the reality that, in Northern Ireland, Sinn Féin has long called for an international truth commission (specifically referencing the South-African example) and the SDLP has historically called for a similar mechanism designed to ensure a 'robust truth process' ${ }^{74}$ Unionists, on the other hand, have long expressed cynicism about whether such truth recovery will ever happen and, instead, have continuously asserted their determination to prevent 'the rewriting of history' by Republicans. ${ }^{75}$ In short, the gradual reduction to zero of discussion on truth recovery and its replacement by information retrieval and information recovery reflects increased buy-in by Unionist politicians in the process of dealing with the past.

Our work on the truth or information recovery aspects of this process has been across a number of areas, in addition to the HIU discussed above. With regard to the now decoupled mechanism (the IRG) to deal with the broader themes of the conflict, the political shape of the compromises made during the Stormont House negotiations on this new institution were very obvious once the text was released. As noted above, the SHA stipulated that the IRG would be overseen by a body of 11 people, all of them political appointees by the local parties and the two governments. ${ }^{76}$ This body would commission a report on themes from independent academic experts. The SHA also stipulated that the work of the IRG should 'be conducted with sensitivity, and rigorous intellectual integrity, devoid of any political interference'. ${ }^{77}$

As detailed in the 'Clause by clause' article, our concern in drafting the Model Bill was therefore to write clauses which maximised the independence of this mechanism. Towards that end, we suggested that it too (like the HIU) should be a body corporate; included some criteria on the qualities and skills of the kind of people who should be appointed to the IRG; imposed a statutory duty on members to act independently and impartially; and suggested provisions on reporting and relations with the other bodies. After the failed negotiations of 2014 recommenced in autumn 2015, most of our energies were channelled into public and private lobbying that the IRG should actually be included in the enabling Westminster legislation after the British government made it clear that it considered that inclusion of the IRG in the primary legislation was not required. It is our understanding that this point, also argued strongly by a number of the political parties and the Irish government, was ultimately conceded in those negotiations and that the IRG will be included in Westminster legislation, although significant details have not been resolved at the time of writing.

73 See, for example, Michel Foucault, The Politics of Truth (Semiotext 1997); W T Anderson (ed), The Truth About Truth (Putman 1995); Ifi Amadiume and Abdullahi An-Na'im (eds), The Politics of Memory; Truth, Healing Justice (Zed Books 2000).

74 'Truth: A Sinn Féin Discussion Document' (Sinn Féin, 2003); 'Addressing the Past: A Comprehensive Truth Process and the Ethical Way Forward' (SDLP 2013).

75 'Dealing with the Past in Northern Ireland' (DUP 2009). For a definitive discussion on the complexities of Unionist attitudes to truth recovery, see Cheryl Lawther (n 50).

76 SHA (n 38) 10.

77 Ibid. 
The other vehicle for truth and information recovery in the SHA is the ICIR. A key challenge of this or any equivalent body is how to encourage those with information which may be of relevance to victims to come forward. As was noted above, this was a specific issue upon which members of the team had been working for many years. In 2007, a detailed report on the issue was submitted to the CGP. ${ }^{78}$ Internationally, much of these kinds of discussions are framed as the 'truth recovery in return for amnesty trade-off' ${ }^{79} \mathrm{It}$ is also true that elements of the Northern Ireland transition can be accurately described as amnesties or amnesty-like measures. ${ }^{80}$ However, in contributing to the Haass-O'Sullivan and Stormont House negotiations, the team ultimately decided to emphasise the longstanding British legal tradition of using limited immunities from prosecution in public inquiries and related investigations into past events rather than pressing for the more contentious term of amnesties. ${ }^{81}$ In 2013 , a proposal submitted from the project team on ways of trading truth recovery for different forms of immunity from prosecution was adapted by the parties and is contained in the final draft agreement presented by Haass and O'Sullivan. It was retained in slightly amended form in the SHA $2014 .{ }^{82}$

In working on the Model Bill, again we sought to ensure the independence and effectiveness of the ICIR: suggesting that it should be a body corporate; specifying a range of victims and survivors who would be able to access its services; and suggesting that the Secretary of State make regulations to require public authorities to provide it with information. In addition, we included a clear statement that 'information provided to the ICIR is not admissible as evidence in criminal or civil legal proceedings'. We also included a requirement for regulations that a person providing information should also not be subject to 'administrative sanctions' (e.g. to protect a state employee from disciplinary proceedings), as well as the power to create offences for people knowingly providing false information, obstructing the work of the ICIR (including public authorities destroying information likely to be required by the ICIR), or disclosure of information by its members or staff. In addition, because the ICIR will have a cross-border dimension and require the completion of an international treaty between the two governments, we included a schedule to our Model Bill with suggested text for that Agreement.

78 Kieran McEvoy and Louise Mallinder, 'Article 2 Compliant Truth Recovery and Guarantees of NonProsecution' (confidential submission to the CGP, 2007).

79 For a detailed discussion, see Louise Mallinder, Amnesty, Human Rights and Political Transitions (Hart 2008); Mark Freeman, Necessary Evils: Amnesties and the Search for Justice (CUP 2009).

80 Kieran McEvoy, Luke Moffett, Louise Mallinder and Gordon Anthony, 'The Historical Use of Amnesties, Immunities and Sentence Reductions in Northern Ireland' (2015) <www.amnesties-prosecution-publicinterest.co.uk/themainevent/wp-content/uploads/2015/03/Historical-Use-of-Amnesties-Report-Final-24March-2015.pdf> accessed 21 March 2016.

81 As one team member suggested in a team meeting, "emphasising that limited legal immunity in return for information provided is as British as Finchley, rather than any fancy transitional justice formulation, will hopefully make it more palatable to Unionists in particular who are highly suspicious of the whole notion of transitional justice'.

82 Kieran McEvoy and Louise Mallinder, 'Truth, Amnesties and Prosecution: Models for Dealing with the Past in Northern Ireland' (Queen's University Belfast 2013). See Liam Clarke, 'Parties Involved in the Haass Talks are Considering Four Possible Models for Setting Aside Prosecutions for Troubles-Era Offences, the Belfast Telegraph Has Learnt' Belfast Telegraph (Belfast, 9 December 2013). In the same story, the leader of the DUP negotiating team Jeffrey Donaldson MP told the Belfast Telegraph: 'We have met with Kieran McEvoy and his colleagues and listened to what they have to say. We have made it clear both in public and in private that we are opposed to amnesties for terrorist murder. However limited immunity is a separate concept.' In the Haass-O'Sullivan document the ICIR is given the power to offer 'inadmissibility' or 'limited immunity' to protect individuals from criminal or civil liability with regard to any statements they make to the ICIR, Haass and O'Sullivan (n 70). In the SHA only the term 'inadmissible' is used, although the legal and practical effects are precisely the same. 
When the leaked version of the UK government legislation became public in late 2015, the inadmissibility of information given to the ICIR for criminal or civil proceedings was confirmed. However, similar to our concerns with regard to the HIU, analogous provisions which required the ICIR to pass copies of the reports (which were due to go families) first to the British and Irish governments to review for 'national security' reasons became the primary focus of our concerns. At the time of writing, those concerns remain.

\section{Oral history, story-telling and the past}

The final element of the Model Bill and SHA mosaic for dealing with the past in Northern Ireland is the OHA. As with the other elements of the SHA, versions of this mechanism have been trailed in previous rounds of negotiation. As early as 1998, the report into victims and survivors commissioned by the then Secretary of State Mo Mowlam highlighted "the value of "telling the story". 83 The CGP provided much fuller detail on the potential role for story-telling, recognising its potentially 'cathartic nature' in enabling people to share their stories with others (especially their former enemies). They envisaged a role for the chair of the Legacy Commission, through a Reconciliation Forum, to promote story-telling schemes and memorial projects and further recommended the collation of stories in some form of archive. ${ }^{84}$ Similarly, the Haass-O'Sullivan document recommended that the Northern Ireland Executive should establish 'an archive for conflict-related oral histories, documents and other relevant materials' for those who 'wish to share their experiences connected with the conflict'. That report, like the SHA, also stipulated that this archive 'will be free from political interference' and, in addition to collecting new material, will function as a repository for existing oral history archives. ${ }^{85}$

The ancient art of story-telling has long since been overtaken by technology, but the central imperative to listen in a measured, humane and respectful fashion continues to underscore the modern oral historian's craft. ${ }^{86}$ Often juxtaposed to the overly legalistic and costly nature of other transitional justice mechanisms (such as trials or truth recovery bodies), advocates highlight the particular appeal of oral history and storytelling approaches in post-conflict or post-authoritarian settings. ${ }^{87}$ This includes the possibility of 'giving voice' to marginalised, victimised and 'subaltern' witnesses and of broadening the canvas for dealing with the past. Thus, neglected themes such as rural experiences of conflict, the intersection of class struggles, mental health and

83 Sir Kenneth Bloomfield wrote: 'As I received passionate letters of ten, a dozen or more pages, or listened to the first-hand account by survivors of their own trauma, I had a growing realisation that, for some at least, the cathartic effect of putting one's experience on record is profound.' Kenneth Bloomfield, 'We Will Remember Them: Report of the Northern Ireland Victims Commissioner', April 1998, ch 3, s 12.

84 CGP (n 68) 97-98.

85 Haass and O’Sullivan (n 70) 35-37.

86 It is beyond the scope of this article to explore the respective boundaries of story-telling, oral history, oral tradition and qualitative interviews. For current purposes, these overlapping approaches and methodologies are understood to embrace individual life narratives, cultural memory and community advocacy, as well as elements of artistic and literary performance. For an overview of the broad field of oral history, see Robert Perks and Alistair Thomson (eds), The Oral History Reader (Routledge 2004) and Donald A Ritchie (ed), The Oxford Handbook of Oral History (OUP 2011).

87 See, for example, Jessica Senehi, 'Constructive Storytelling: A Peace Process' (2002) 9(2) Peace and Conflict Studies 41-63; and 'Building Peace: Storytelling to Transform Conflicts Constructively' in Dennis J D Sandole, Sean Byrne, Ingid Sandole Staroste and Jessica Senehi (eds), Handbook of Conflict Analysis and Resolution (Routledge 2009) 201-15. 
generational shifts can be examined. ${ }^{88}$ In addition, oral history provides a platform to explore the gendered dimensions of conflict, providing 'under the radar' opportunities to document difficult and sensitive issues concerning domestic violence and other gender-based harms. ${ }^{89}$ Affording space for the complex, contradictory and sometimes inchoate nature of individual experience also creates important opportunities for victims and survivors to tell their stories in full and in context, at a time and place that best suits their needs. ${ }^{90}$

In the Northern Ireland context, many existing oral history projects have set out to: amplify 'unheard voices'; provide a counterbalance to official narratives; offer some form of redress for victims and survivors; underscore advocacy and community action; and share lessons with other societies. ${ }^{91}$ In many ways, the 'piecemeal' nature of efforts to deal with the past discussed above increases the significance of this type of work. ${ }^{92}$ In the absence of an overarching truth mechanism, academic and community oral history and story-telling projects in Northern Ireland have provided some of the few available options for those who want to have their experiences and their consequences recorded and acknowledged. ${ }^{93}$ The WAVE Trauma Centre victims' group, for example, has developed a range of story-telling projects to capture the experience of those who were either bereaved or injured as a result of the conflict. ${ }^{94}$ Other projects have concentrated on the experience of specific communities, particularly those most affected by the conflict. ${ }^{95}$ Former combatants, in particular, Republican ex-prisoners, have worked collectively to coordinate the story of their prison experiences and to link this to outreach, reconciliation and support work. ${ }^{96}$ Significant impetus was injected into the sector by the European Union's Peace III Programme which funded dozens of oral

88 See further Anna Bryson, 'The Interview: A Tool for Peace Building? Reflections on the Peace Process: Layers of Meaning Project' (2014) 9 Journal of Cross Border Studies in Ireland 79-90.

89 In Northern Ireland, for example, it has been suggested that there has been a sustained exclusion of women from dealing with the past initiatives and that the gendered impact of the conflict and post-conflict legacy needs of women thus have not been adequately addressed. See 'Gender Principles for Dealing with the Past' (Legacy Gender Integration Group September 2015) 2 <www.rwuk.org> accessed 14 November 2015.

90 Sean Field, “'Beyond Healing”: Trauma, Oral History and Regeneration’ (2006) 34(1) Oral History 31-42 and 'Disappointed Remains: Trauma, Testimony and Reconciliation in Post-Apartheid South Africa' in Ritchie (n 86) 142-58; Stephen M Sloan, 'The Fabric of Crisis: Approaching the Heart of Oral History' in Mark Cave and Stephen M Sloan (eds), Listening on the Edge: Oral History in the Aftermath of Crisis (OUP 2014) 262.

91 See Anna Bryson, 'Victims, Violence and Voice: Transitional Justice, Oral History and Dealing with the Past' (2016) 39(2) Hastings International and Comparative Law Review 299-353.

92 See 'Preliminary Observations and Recommendations by the Special Rapporteur on the Promotion of Truth, Justice, Reparation and Guarantees of Non-recurrence, Pablo de Greiff, on his Visit to the United Kingdom of Great Britain and Northern Ireland' (9-18 November 2015) <www.caj.org.uk/files/2015/ 11/18/PDG_Statement1.pdf> accessed 19 November 2015.

93 Much of the work in this area has been co-ordinated and led by the cross-community NGO, Healing Through Remembering.

94 Relevant storytelling projects include: 'Injured on that Day', 'Don't You Forget About Me' and 'Unheard Voices'. See: <www.wavetraumacentre.org.uk/about-us/wave-projects/unheard-voices> accessed 17 November 2015.

95 Notable examples include the Falls Community Council Dúchas project developed in the late 1990s to record the experience of the conflict in nationalist West Belfast <www.duchasarchive.com> accessed 15 March 2016 and the RUC George Cross Foundation oral history project which focuses on experiences of former members of the RUC between 1922-2001 <www.rucgcfoundation.org/oral-history> accessed 19 November 2015.

96 See Brian Gormally and Kieran McEvoy, Conflict Transformation from the Bottom Up (2011), unpublished author's copy. 
history and story-telling projects. ${ }^{97}$ In view of the participatory nature of the method, it is not surprising that a number of academic-led oral history projects have been predicated on community engagement and cooperation. ${ }^{98}$ In keeping with the international trend, some of the most powerful work has developed at the interface of oral testimony and the arts. Outputs here include 'theatres of witness' and interview-based plays and novels. ${ }^{99}$

In light of the plethora of local oral history projects and expertise and the longstanding need to provide a central repository for accounts of the conflict, the SHA (correctly in our view) stipulated that 'as well as collecting new material, this archive will attempt to draw together and work with existing oral history projects'. ${ }^{100}$ In our work on the Model Bill, we thus began our deliberations by focusing on how the OHA might complement and facilitate existing groups and organisations. At an early stage in our consultations it became clear that many existing projects feared what might be described as a 'Tesco' or 'Walmart' effect, i.e. that a new central archive would challenge and ultimately threaten their existence. Others expressed concerns that, in the absence of proactive and fulsome engagement with existing groups, the new archive would inevitably run the risk of repeating the mistakes of the past. To allay these concerns, it was clear that the governance model would have to reflect the need to ensure good and mutually productive relations with existing organisations. As with other aspects of the Model Bill process, we drew upon best practice elsewhere - in particular looking at models employed by organisations such as the Digital Public Library of America and the Royal Irish Academy, as well as local umbrella groups, such as Healing Through Remembering. ${ }^{101}$

As is detailed further in the 'Clause by clause' article, the governance structure we ultimately settled on proposed that the Public Records Office of Northern Ireland (PRONI) - subject to the necessary checks and balances - could function as the shell for the proposed OHA. Crucially, however, we included provisions to give the OHA statutory independence. It would be established by the First and Deputy First Ministers, acting jointly, and governed by three executive directors (one of whom would be appointed in consultation with the Dublin government). In addition, we suggested that a strong and diverse Advisory Board (provided for in statute) would represent the interests of existing oral history projects and networks and would assist the Executive Board with the development of strategy and policy, objectives and priorities. We also included provisions to enable this board to oversee complaints, financial regulation and the submission of reports to the IRG. The day-to-day work (research, outreach, interviewing, archiving and administrative support) would be undertaken by a Secretariat and the necessary skills and attributes for all office-holders were set out in some detail in the

97 Major projects funded include The Peace Process: Layers of Meaning Project <www.peaceprocesshistory.org> accessed 19 November 2015; Diversity Challenges, 'Green and Blue Across the Thin Line' <www.green-andblue.org> accessed 19 November 2015; and Border Lives <www.borderlives.eu/project> accessed 19 November 2015.

98 See, for example, the Ardoyne Commemoration Project, Ardoyne: The Untold Truth (Beyond the Pale 2002).

99 See, for example, <www.theatreofwitness.org> accessed 17 November 2015.

100 SHA (n 38) paras 22-24.

101 The Digital Public Library of America provides a particularly instructive example. In 201040 leaders from libraries, foundations, academia and technology projects across America came together and agreed to work together to create 'an open, distributed network of comprehensive online resources that would draw on the nation's living heritage from libraries, universities, archives, and museums in order to educate, inform, and empower everyone in current and future generations'. After much deliberation it settled on a governance model based on partnership agreements with existing stakeholders and an Executive Director who works under the guidance of a Board of Directors comprised of leading public and research librarians, technologists, intellectual property scholars and business experts from across the USA. See <www.dp.la/info/about/history> accessed 14 July 2015. 
Model Bill. In addition, to ensure adherence to international best practice, we made provision for a detailed Code of Practice (with particular guidelines for work with specific groups, such as victims and young people). We also proposed a central 'training the trainers' model as a cost-effective way of enabling the OHA to operate with as much flexibility and reach as possible. To avoid a narrow and inward-looking approach, we tailored the governance structure to ensure meaningful participation and input from agencies and victims and survivors 'throughout the UK and Ireland'. 102 Finally, in the drafting of the Model Bill, and our related policy work and engagement with stakeholders, we were concerned to counter the apparent assumption (which appeared to be shared by some politicians and officials) that the OHA could be largely passive in enabling people from 'throughout the UK and Ireland' to participate and contribute. Based on our own previous experience, we argued strongly that ensuring participation from a suitably broad range of victims and others demanded careful anticipation, consultation, outreach, reflection and persuasion. ${ }^{103}$

Other than the governance and outreach functions of the OHA, the obvious practical challenge which has overshadowed our own work and that of the officials working on the legislation has been the 'fear factor' associated with the Boston College Tapes project. Commencing in 2001, a prominent journalist, Ed Moloney, and two researchers, interviewed approximately 40 former members of Republican and Loyalist paramilitary organisations on behalf of Boston College, with the proviso that their interviews would not be made public until after their death. Public attention was drawn to the archive following the publication of two of the interviews (with recently deceased interviewees), in a book and documentary, and by media coverage of an exchange with one of the interviewees which suggested that the tapes contained information about some of the most notorious crimes of the Troubles. The British government (on behalf of the PSNI) subsequently contacted the US Department of Justice requesting (under the terms of the UK-US Mutual Legal Assistance Treaty) to subpoena 'any and all interviews' containing information about the murder of Jean McConville. In December 2011, Judge William Young ruled against both Boston College and the project researchers and ordered that the relevant material be handed over, a decision that was upheld by a three-judge US Federal Appeal Court in July 2012. A number of high-profile political activists were subsequently arrested, including senior loyalists, veteran Republican Ivor Bell and the President of Sinn Féin, Gerry Adams, who was subsequently released without charge. ${ }^{104}$

This controversy underlined in the sharpest possible terms that, under current legislation, oral history archives cannot offer a cast-iron guarantee of confidentiality. We proposed to address this by emphasising the need for training on issues of ethical and legal probity and by stating clearly that the OHA would not accept information about crimes that had not been processed and fully determined by the courts of all relevant jurisdictions. At the same time, we recognised the danger of the OHA becoming overlaid

102 Some victims and survivors based in Britain have understandably expressed concerns that the OHA could easily become too 'Northern Ireland-centric'. See Nick Taylor, chief executive of the Tim Parry, Jonathan Ball Foundation for Peace <www.foundation4peace.org/foundation-sets-out-ambition-to-become-gb-oralhistory-archive $>$ accessed 2 December 2015.

103 See further Anna Bryson and Seán McConville, The Routledge Guide to Interviewing: Oral History, Social Enquiry and Investigation (Routledge 2014).

104 See Will Havemann, 'Privilege and the Belfast Project' (2010) 79 Stanford Law Review Online 79-85; McEvoy (n 24) 56-58. 
by an excessively bureaucratic and legalistic approach. ${ }^{105}$ We also acknowledged that one of the unfortunate legacies of the Boston College Tapes project is that many oral history projects (however innocuous or apolitical) have become uneasy about depositing their materials with archives. To mitigate the possibility of the OHA becoming an anodyne repository of 'safe' and unchallenging narratives, we proposed that the Data Protection Acts and the Freedom of Information Act 2000 should not apply to material deposited with the proposed archive until such times as accounts have been published (i.e. reviewed by contributors and approved for release by the appropriate staff members). This is not designed to encourage information about material that could be deemed defamatory or otherwise controversial. Rather, it simply acknowledges the considerable sensitivity of 'experiences and narratives related to the Troubles' and the need to encourage and facilitate as wide a range of contributions as possible. Whilst contributions to the archive should, for the most part, be accessible online, we also proposed that opportunities should be provided for people to hear and share their respective stories in a central, inclusive and welcoming space.

Such assurances arguably amount to very little unless the fundamental issue of trust, or what we describe here as 'grass-roots credibility', is addressed. This speaks to a core stipulation set out in the SHA that the archive 'will be independent and free from political interference'. At an early point in the negotiations on the outworking of the SHA, the PRONI was invited to scope out various options for the development of the OHA. With the tacit agreement of the five main political parties, this quickly solidified into a proposal that the proposed archive should be under the charge and superintendence of the Deputy Keeper of PRONI. As PRONI is an executive agency of the Department of Culture, Arts and Leisure, this immediately raised concerns for us and others about its independence. Those who have attempted to develop sensitive cross-community projects know all too well that political interference is to be avoided at all costs. ${ }^{106}$ Suggestions that the Deputy Keeper would have 'operational independence' from his/her keeper (the prevailing minister) in respect of the OHA did little to allay fears. ${ }^{107}$ The issue of ministerial control of documents is but one element of a much wider conundrum. Operational independence is well and good in theory but, in light of organisational impulses and constraints, it is difficult to envisage a career civil servant closing his or her ears to the clearly expressed wishes of their direct minister. And, at any rate, the proposal to entrust to the Deputy Keeper all power to control and direct the OHA, including decisions about which records to include and which to destroy and if, how and when to engage 'expert practitioners', remains highly problematic. Discussions with politicians and policy-makers on these and related issues concerning the OHA are ongoing at the time of writing.

In summary, like others involved in these discussions, we have long since been persuaded of the short and long-term need for an effective overarching strategy for oral history, story-telling and the conflict. What future generations make of the conflict in

105 For an analysis of the impact that risk aversion has had on research topics, see Ted Palys and John Lowman, 'Going Boldly Where No One Has Gone Before? How Confidentiality Risk Aversion is Killing Research on Sensitive Topics' (2010) 8(4) Journal of Academic Ethics 265-84.

106 For example, in spite of a carefully crafted 124-page 'Masterplan and Implementation Strategy' (including plans for an international centre for conflict transformation) underscored by significant and costly research and consultation, the Maze-Long Kesh Regeneration project was effectively stalled overnight due to political disagreement.

107 See further Anna Bryson, 'The Stormont House Oral History Archive, PRONI and the Meaning of Independence' <www.rightsni.org/2015/10/the-stormont-house-oral-history-archive-proni-and-themeaning-of-independence-guest-post-by-dr-anna-bryson $>$ accessed 15 October 2015. 
Northern Ireland will be significantly swayed by the source material we bequeath to them. ${ }^{108}$ What is missing from official documentation on the proposed OHA is any hint of a vision. Articulation of such a vision demands careful reflection on complex concepts, such as reconciliation, victimisation, truth and reconciliation; reflections that will in turn inform the acquisitions and preservation policy - the essential contours of the mechanism. Cast in the right mould, the OHA could make a valuable contribution to the process of dealing with the past and, ultimately, to reconciliation. Past experience dictates that grasping the nettle of reconciliation requires long-term vision and a departure from penny-wise, pound-foolish approaches. If there is a silver lining to the recent failure to agree a legislative framework for dealing with the past, it is that the various opportunities and challenges outlined here might be debated more fully before institutional and legal parameters are set in stone.

\section{Conclusion}

At the time of writing, the authors and our colleagues on the Model Bill team are still working intently with officials from both governments, as well as other political and civil society actors, to overcome the remaining obstacles to finally 'deal with the past' in Northern Ireland. There is a widespread agreement that we are 'closer than ever before' 109 and we are confident that, with political will and some legal imagination, these remaining obstacles are resolvable. However, given the fact that they are yet to be resolved, it is perhaps too early to be overly definitive about the lessons to be learned from the Model Bill process and the related policy and advocacy work which has preceded and accompanied this project. By definition therefore, these conclusions must at this stage remain somewhat tentative. With such caveats duly noted, we would suggest that there are at least three overlapping themes which emerge which may be of interest to activists seeking to influence transitional justice processes 'from below' elsewhere. These can be summarised as technical capacity, grass-roots credibility and providing 'international-savvy' local solutions.

Both governments, other civil society organisations and a number of the political actors involved have publicly acknowledged the value and worth of the technical contribution of the project to date at various conferences, seminars and events. For example, in a letter to our project partner, the Committee on the Administration of Justice, the current Under-Secretary of State for Northern Ireland said:

I would like to acknowledge the input that you and others have brought to the shadow bill project, and I know my officials have found this to be a useful and innovative way of engaging in parallel with the development of the Bill. In addition the events and workshops which you have hosted have facilitated the expression of the views of stakeholders on these important issues. ${ }^{110}$

108 A telling example in the Irish context is provided by the 1773 Witness Statements concerning the 1913-1921 revolutionary period which were collected on behalf of the Irish state between 1947 and 1957. Together with the Military Service Pensions collection these accounts (now available online) have profoundly influenced the historiography of this critical period in Irish history. See, for example, Marie Coleman, The Irish Revolution, 1916-1923 (Pearson 2013) and Diarmaid Ferriter, A Nation and Not a Rabble: The Irish Revolution, 1913-23 (Profile Books 2015).

109 Secretary of State for Northern Ireland Teresa Villiers, 'Speech on the Independent Commission on Information Retrieval' 21 January 2016 <www.ukpol.co.uk/2016/02/10/theresa-villiers-2016-speech-on-theindependent-commission-on-information-retrieval/> accessed 15 March 2016.

110 Letter from Under-secretary of State for Northern Ireland Ben Wallace MP, 23 September 2015. See Anne Skorkjær Binderkrantz, 'Customizing Strategy: Policy Goals and Interest Group Strategies' (2012) 1(1) Interest Groups and Advocacy 115-38. 
Drafting legislation is by definition a complex and specialist undertaking. As in other contexts, 111 having what Binderkrantz has referred to as 'technical insight' has undoubtedly afforded the team access and influence with key players. ${ }^{112}$ As Beyers, Weiller and Brandli and others have argued, such technical expertise may be particularly valued by policy-makers, officials and other who are working in complex and sensitive areas. ${ }^{113}$ Indeed, precisely because of the politically sensitive and legally complex issues involved, an 'institutional opportunity structure'114 existed for the provision of measured, detailed and technically sound interventions. Nothwithstanding inevitable disagreements on policy and principle, the ability to 'speak the same language' on the technical aspects of the debate helped create a variant of an 'epistemic community' between the Model Bill team and government officials. ${ }^{115}$

However, the process has involved much more than the provision of technical information. In reviewing the relevant literature on political and policy advocacy, we have arguably been involved in both 'insider tactics' (e.g. engaging with the political actors and government officials) and 'outsider tactics' (e.g. a sustained campaign of media and civil society engagement). ${ }^{116}$ Queen's Law School and its Human Rights Centre, in particular, together with the Transitional Justice Institute at Ulster University, have a significant reputation for their commitment to making an impact in the 'real world'. Notwithstanding those profiles, we would argue that the partnership with the Committee on the Administration of Justice (Northern Ireland's primary human rights NGO) on the Model Bill process and with Healing Through Remembering (the jurisdiction's primary 'dealing with the past' NGO) on the broader truth recovery, immunities and oral history work was crucial in emphasising that this was 'not just an academic exercise' for those involved.

Equally critical has been the team's openness to applying international knowledge and experience to the local. As Nelken has argued, one of the key advantages of comparative legal scholarship is not only that it allows us to 'make sense of difference', but that it also allows us to move beyond the essentialising tendencies of our own context and to consider and present local problems in a different light. ${ }^{117}$ For some audiences, the team's ability to draw upon international law (in particular, the jurisprudence of the European Convention on Human Rights), as well as transitional policy and practice elsewhere, was a clear advantage. However, as evidenced with the interventions concerning the truth and

111 See, for example, R A W Rhodes and David Marsh (eds), Policy Networks in British Government (OUP 1992); PerOla Öberg, Torsten Svensson, Peter Munk Christiansen, Asbjørn Sonne Nørgaard, Hilmar Rommetvedt and Gunnar Thesen, 'Disrupted Exchange and Declining Corporatism: Government Authority and Interest Group Capability in Scandinavia' (2011) 46(3) Government and Opposition 365-91.

112 See Anne Skorkjær Binderkrantz, ‘Customizing Strategy: Policy Goals and Interest Group Strategies’ (2012) 1(1) Interest Groups and Advocacy 115-38.

113 Jan Beyers, 'From Transitional to Transformative Justice: A New Agenda for Practice' (2004) 5(2) European Union Politics 211-40; Florian Weiler and Matthias Brändli, 'Inside Versus Outside Lobbying: How the Institutional Framework Shapes the Lobbying Behaviour of Interest Groups' (2015) 54(4) European Journal of Political Research 745-66.

114 Andreas Dür and Gemma Mateo González, 'Gaining Access or Going Public? Interest Group Strategies in Five European Countries’ (2013) 52(5) European Journal of Political Research 660-86.

115 See Peter Haas, 'Epistemic Communities' in Joel Krieger (ed), The Oxford Companion to Comparative Politics (OUP 2012) 351-59; Mai'A K Davis Cross, 'Rethinking Epistemic Communities Twenty Years Later' (2013) 39(1) Review of International Studies 137-60.

116 Beyers (n 113); Hanspeter Kriesi, Anke Tresch and Margit Jochum, 'Going Public in the European Union Action Repertoires of Western European Collective Political Actors' (2007) 40(1) Comparative Political Studies 48-73.

117 David Nelken, ‘Comparative Criminal Justice: Beyond Ethnocentricism and Relativism' (2009) 6(4) European Journal of Criminology 291; and Comparative Criminal Justice: Making Sense of Difference (Sage 2010). 
immunity debate discussed above, in other contexts such knowledge and experience was probably less persuasive than British public law policy and practice. As is evidenced by the design of all of the past-focused institutions in the SHA, 'bespoke local solutions' (in some instances clearly influenced by international experience whether or not this was expressly articulated) were required in order to reach political consensus.

Over a quarter of a century ago, the legendary sociologist Stan Cohen wrote compellingly about the difficult balancing act for academics between their natural intellectual scepticism and their moral and political obligations to try to make a difference, to 'engage'. ${ }^{118}$ Given the difficulties associated with dealing with the past in Northern Ireland over the past two decades, we would be lying if we didn't admit that there have been times when we have been beyond frustration at the inability of our politicians to 'do the deal' on the issue. Needless to say, our frustrations are as nothing compared to those of the victims and survivors who were directly affected by the conflict. ${ }^{119}$ The Model Bill process and related work has presented us with a classic 'window of opportunity' in political terms where three elements came together: a complex series of problems; the opportunity to develop and refine proposals to address those problems; and the possibility of political change. ${ }^{120}$ Regardless of the ultimate outcome, the process of engagement has been a privilege.

118 Stan Cohen 'Intellectual Scepticism and Political Commitment: The Case of Radical Criminology' in Paul Walton and Jock Young (eds), The New Criminology Revisited (Macmillan 1990) 98-130.

119 As the Chief Executive of the Wave Trauma Centre victims' organisation put it when the news emerged that the 2015 Stormont House Fresh Start Agreement had yet again failed to include a 'deal' on dealing with the past: 'The two Governments and political parties have said that dealing with the suffering of victims and survivors is central to Northern Ireland moving forward. They can no longer say that with any credibility. The reality is that they have abandoned and betrayed victims and survivors who have repeatedly been promised that there would be an inclusive and comprehensive way found to deal with the legacy of the past. Victims and survivors were told to wait for Eames/Bradley but they got nothing. They were told to wait for Haass-O'Sullivan and got nothing. They were told to wait for Stormont House and got nothing. Now they have been given a document that with absolutely no hint of irony is being called a "Fresh Start" and there is nothing beyond a vague reference to continuing to "reflect". Where is the "fresh start" for them? ... perhaps the saddest, most depressing aspect of all this is that while they are shocked, disgusted and beyond disappointment they are not surprised.' See 'Where is the Fresh Start for Them?', press release, Wave Trauma Centre, 18 November 2015' <www.wavetraumacentre.org.uk/news/where-is-the-fresh-start-for-them> accessed 3 March 2016.

120 John W Kingdon, Agendas, Alternatives, and Public Policies (Little Brown 1984). 